\section{PP-413 HLA class II DQ Antibody Production Before Kidney Graft Failure}

\author{
テラサキファウンデーション ${ }^{1)}$, マイアミ大学 ${ }^{2)}$ \\ 水谷 一夫 ${ }^{1)}$ ，エクキュエナージ バイオレット ${ }^{2}$, \\ ミラー ジョシュア2),テラサキ ポール
}

Aims: HLA DQ is one of the new HLA inetrested parts to effect graft failure. In addition, single antigen beads method allows us to detect specific antibodies like donor-specific antibody(DSA). Therefore, we focused on DQ antibody of kidney transplants. Methods: We retrospectively examined DQ antibodies from 65 patients who rejected their grafts (Graft failure group:GF) and 33 functioning patients as controls.(Functioning group:GS) Two Samples were selected each patient; One was drawned at pre- or early post-transplant period. Another samples were collected at before-failure(GF) or recent periods (GS). Results: DQ antibodies were found in a significantly higher incidence among GF (28\%) than GS (9\%) (p < 0.05). Among 18 who had DQ antibodies in the GF, $13(72 \%)$ had DQ DSA. In addition, positive patients of DQ DSA had higher Fluorescent Intensity(FI) than those of DQ non-DSA. ( $p<0.05$ ) Conclusions: These results indicate that $\mathrm{DQ}$ antibodies might be the cause of filure and more frequently present than among those who had functioning grafts, and FI could be imporant for monitoiring of graft failure.

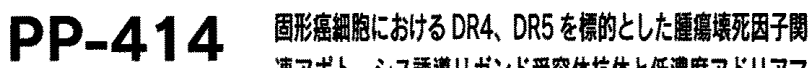

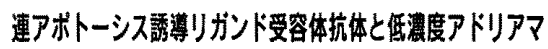

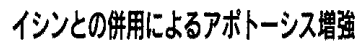

\author{
香川大学医学部泌尿器科学 \\ 舆 秀賢，アハメド マムド アプデリ ハメド， \\ 乾 政志, 杉元 幹史, 筧 善行
}

【目的】腫腸壊死因子関連アポトーシ久誘導りガンド (TRAIL) 受容体 である Death receptor 4 及び 5 (DR4 及び DR5) は新規分子標的として 注目されている。我夕は固形癌細胞を用いて、DR4、DR5 を標的とした 抗DR4、DR5 モノクロナル抗体 HGS-ETR1、HGS-ETR2 と種々の低濃 度抗癌剂との併用効果を検㑏し、その作用機構を解析した。【方法】細胞 障害活性はMTT 試験にて測定し、相乗效果の有無はIsobolography 法 で解析した。DR4、DR5の発現はWestern Blotなどで解析した。結果】 ACHN腎癌株化紐胞をHGS-ETR1、HGS-ETR2とアドリアマイシン(ADR)、 5-Flurouracil または Vinblastine とで併用処理したところ、ADRとの組み 合わせのみが相乗効果を示した。この相乗効果はNucleoCounterでも確 認された。初期腎癌培盖細胞、前立腺癌、膀胱癌、肺癌細胞に対しても同 柡な相乗効果が翀められた。処理の順序を検討したところ、先にADRで 処理した後HGS-ETR1 または HGS-ETR2で处理した方が腎癌細胞に対す る細胞障害活性が有意に強加た $(\mathrm{P}<0.05)$ 。また、低濃度の ADR (0.1-1 $\mathrm{ug} / \mathrm{ml}$ ) 愊癌細胞におけるDR4、DR5の発現を顕著に増強した。さらに、 ADR と HGS-ETR1/HGS-ETR2 併用によるカスパーゼ活性化とアポトー シス増強加観察された。考察】固形癌に対する抗TRAIL 受容体抗体と 低濃度 ADR との併用治潦が有望であることが示唆された。

\section{PP-415 挤細胞宿における RASSF1A メチル 化の不均一性とその生物学的意義}

\author{
京都大学大学院医学研究科泌尿器科学 ${ }^{1)}$, Otago \\ University, Cancer Genetics Laboratory ${ }^{2)}$ \\ 渡部 淳 $^{1)}$, 伊藤 哲之 ${ }^{1)}$ ，小川 修 ${ }^{1)}$ ， \\ Anthony Reeve ${ }^{2)}$
}

【目的】 RASSF1A は Ras 経路の構成分子であり、淡明型腎細胞癌 (CRCC)にて高頻度にメチル化を受计うる癌抑制遗伝子のひとつであ る。今回我々は CRCC 組織の RASSF1A 活性化状態の不均一性につ いて報告をする。【対象と方法】当科にて加療をうけたCRCC58 症 例を対象とした。各症例の腫湯および正常腎よりDNA，RNAを抽 出、プロモーター領域、Exonl 領域の 2 所ににおけるメチル化状態 を methylation specific PCRにて評価、またその発現状態は定量的 PCRにて評価した。【結果】 CRCC 症例の正常腎の大部分において 高メチル化がおきていることが判明した (Exon1:97\%，プロモーター： 67\%)。一方腫場組織では、58\%の症例において、正常腎に比較しメ チル化の維持・増加を認めたが、42\%の症例ではむしろ減少してお り且つG3 腫瘍の頻度が有意に高かった。このメチル化は mRNA 発 現量と有意に相関し、転写制御を反映していると考えられた。考 察I RASSFIA の高メチル化は正常腎において加龄にともない進行 する。Low grade腫瘍は発癌に伴いその高メチル化を引き継ぐが、 一方 High grade 腫瘍ではそのメチル化頻度は低く、両者は異なった epigenetic process を経て癌化に至る可能性がある。

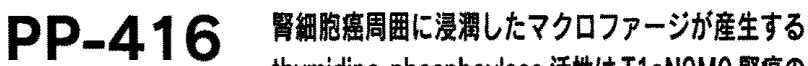

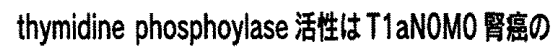

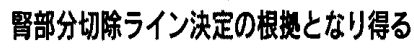

[目的] thymidine phosphoylase (TP) 江血管新生を促し、睡湟の浸潤や転移に関 与していると考えられている。今回我々は、睡場加ら $5 \mathrm{~mm}$ の腎部分切除て、、根治

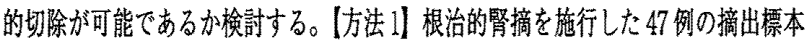

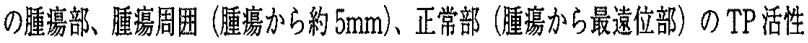
の激定と抗 TPモノクローナル抗体と HAM56 て免疫染色し、臨床病理学的因子と

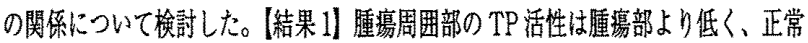

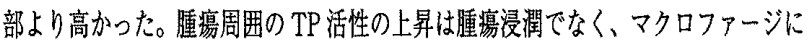

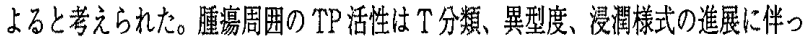

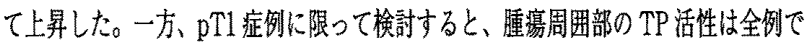

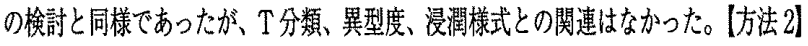

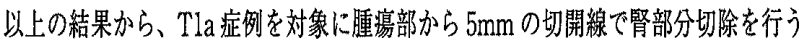
prospective study を計面した。結果2!11例に対して腎部分切除を施行した。平

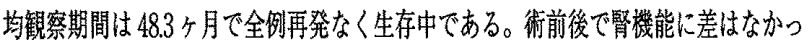

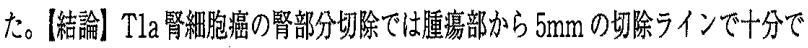
あり，根治的切除梱可能であることが示陵された。 